\title{
Tertiary treatment of dairy industry wastewater with production of Chlorella vulgaris biomass: evaluation of effluent dilution
}

Tratamento terciário de efluente de indústria de laticínios com produção de biomassa de Chlorella vulgaris: avaliação da diluição do efluente

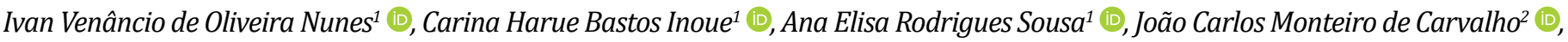
Andreia Maria da Anunciação Gomes ${ }^{3}$ (D), Marcelo Chuei Matsudo ${ }^{1}$ (D)

\section{A B S T RA C T}

Secondary wastewaters from the dairy industry may cause eutrophication of water bodies when not properly treated, mainly because they contain nutrients such as phosphorus and nitrogen. Tertiary treatment using microalgae could be an adequate solution for Minas Gerais State, the largest Brazilian milk producer, contributing to the reduction of environmental impacts, as well as providing biomass for oil extraction, and obtaining active compounds and inputs (including proteins) for animal feeding. In this work, dilutions (with distilled water) of the secondary wastewater from the dairy industry were evaluated to cultivate Chlorella vulgaris in a bench-scale tubular photobioreactor. Theresults indicate the feasibility of using wastewater from the dairy industry, after secondary treatment, to cultivate microalgae, showing cell growth like that obtained in control cultures (Bold basal medium). The secondary wastewater without dilution (100\% wastewater) provided the best condition for biomass production. The biomass obtained in wastewater showed no differences from the biomass obtained in the Bold basal medium (control) in terms of protein, lipid content, or fatty acid profile.

Keywords: microalgae; biomass; tertiary wastewater treatment; dairy products; lipids.

\section{RE S U M 0}

Efluentes secundários da indústria de laticínios, quando não tratados adequadamente, podem provocar eutrofização de corpos d'água, principalmente por conter nutrientes como fósforo e nitrogênio. O tratamento terciário empregando microalgas poderia ser uma solução adequada para o estado de Minas Gerais, maior produtor brasileiro de leite, contribuindo na redução de impactos ambientais, bem como fornecendo biomassa para extração de óleos e obtenção de compostos ativos e insumos (incluindo proteínas) para nutrição animal. Neste trabalho, avaliaram-se diluições (com água destilada) do efluente secundário da indústria de laticínios para cultivo de Chlorella vulgaris em fotobiorreator tubular em escala de bancada. Os resultados encontrados indicam a viabilidade do uso de efluente de indústria de laticínios, pós tratamento secundário, para o cultivo de microalgas, apresentando crescimento similar àquele obtido em cultivos padrões (meio basal Bold). O efluente secundário sem diluição (100\% efluente) foi o que apresentou melhor desempenho na produção de biomassa. Além disso, a biomassa obtida em efluentes não apresentou diferenças em relação àquela obtida em meio basal Bold (controle), no que se refere a teores de proteínas, lipídios ou perfil de ácidos graxos.

Palavras-chave: microalga; biomassa; tratamento terciário de efluente; laticínios; lipídios.

\footnotetext{
${ }^{1}$ Universidade Federal de Itajubá - Itajubá (MG), Brazil.

${ }^{2}$ Universidade de São Paulo - São Paulo (SP), Brazil.

${ }^{3}$ Instituto Federal de Educação, Ciência e Tecnologia do Rio de Janeiro - Rio de Janeiro (RJ), Brazil.

Correspondence address: Marcelo Chuei Matsudo - Avenida Benedito Pereira dos Santos, 1.303 - Pinheirinho - CEP: $37500-903$ - Itajubá (MG), Brazil. E-mail: mcmatsudo@unifei.edu.br
}

Conflicts of interest: the authors declare no conflicts of interest.

Funding: National Council for Scientific and Technological Development (CNPq), grant number 402658-2013-2.

Received on: 05/08/2020. Accepted on: 01/21/2021.

https://doi.org/10.5327/Z21769478787 


\section{Introduction}

Currently, the dairy industry represents an activity of great importance in the world economy, with Brazil standing out with an annual production exceeding 35 billion liters (EMBRAPA, 2018). In this country, Minas Gerais State is its main producer, accounting for approximately $26 \%$ of the national milk production (CONAB, 2018).

The high milk production in Minas Gerais State can cause a problem related to the generation of liquid wastewater by the dairy industries, since the amount of generated residual water can significantly exceed the volume of processed milk, varying from 1 to 6 liters of water/ $\mathrm{kg}$ of milk received (Maganha, 2006).

This type of wastewater originates from different dairy industry operations, such as cleaning equipment and surfaces, sanitizing, heating, and cooling. Consequently, this wastewater has a high BOD load (biochemical oxygen demand), COD (chemical oxygen demand), suspended solids (including oils and fats), dissolved organic compounds (mainly lactose and proteins), besides nutrients such as ammonia and phosphates (Sarkar et al., 2006).

When the amount of nutrients in these wastewaters presents high values, mainly nitrogen and phosphorus, it can cause the eutrophication phenomenon if dumped in a water body without additional treatment. It results in the accelerated proliferation of aquatic macrophytes, microalgae, and cyanobacteria, producing toxic substances, besides causing fish mortality, reducing species diversity, among other serious environmental problems (Maganha, 2006; Barreto et al., 2013).

To meet the environmental requirements, dairy industries can perform:

- preliminary treatments, such as via coarse screens (removal of coarse solids), grit chambers, and grease traps;

- secondary treatments involving biological processes, such as activated sludge, anaerobic filter, up flow anaerobic sludge blanket reactor (UASB), and stabilization ponds (Machado et al., 2001).

Besides these two treatments, there is a tertiary treatment, involving the removal of carbonates, ammonium, nitrate, and phosphate. However, it is rarely performed due to the high cost of the techniques that must be applied. Thus, a way to solve this problem would be through treatment involving microalgae cultivation, using residual water from stabilization ponds as a growth medium (Lourenço, 2006).

In general, biological wastewater treatment is considered more advantageous over chemical treatment, both ecologically and economically. In this context, the use of microalgae can have great potential for application, given the efficiency in the assimilation of carbon dioxide, as well as in the removal of nutrients such as nitrogen and phosphorus (Chinnasamy et al., 2010). Microalgae can remove up to $90 \%$ nitrogen and $96 \%$ phosphorus from liquid wastewaters (Kothari et al., 2013).

The cultivation of microalgae is an efficient option in the tertiary treatment of wastewaters due to their ability to rapidly develop in en- vironments with high loads of nitrogen and inorganic phosphorus and in mitigating the greenhouse effect caused by excessive $\mathrm{CO}_{2}$ emissions. Moreover, the applicability of the biomass resulting from this process is a promising opportunity since, in addition to removing nutrients, this biomass contains compounds with commercial interest, e.g., pigments and lipids. Therefore, these biomolecules provide us with additional gain, e.g., obtaining inputs for food supplements, drugs, and biofuels (Borowitzka, 1999; Derner et al., 2006; Venkatesan et al., 2006). Besides that, microalgae biomass, along with the effluent from stabilization ponds, can be applied in agriculture and fish farming (Sousa, 2007; Mata et al., 2010).

Microalgae can be grown in open (race-way systems and tanks) or closed systems (photobioreactors). Closed systems have been increasingly studied more recently, due to the effectiveness in controlling these microorganisms' growth and promoting better monitoring of their physical and chemical parameters (Carvalho et al., 2014).

Chlorella species have been successfully employed in several studies regarding wastewater treatment (Gupta et al., 2016; Choi et al., 2018; Rodrigues-Sousa et al., 2021). Kothari et al. (2012) observed not only the possibility of producing Chlorella pyrenoidosa biomass in pre-treated dairy industry wastewater, but also the efficiency of this microalgae in removing nitrogen and phosphorus. Moreover, Peng et al. (2019) observed that the organic compounds, present in wastewater, increase the microalgae biomass productivity through the mixotrophic growth and Bellucci et al. (2020) employed different microalgae species community (including Chlorella spp.) for the tertiary treatment municipal wastewater, indicating that these photosynthetic microorganisms also contributed to the disinfection of wastewater.

In this context, the present work evaluated the use of secondary wastewater from the dairy industry (after primary and secondary treatments) for cultivating the microalgae Chlorella vulgaris, having the wastewater dilution as an independent variable and comparing the data of cell growth, biomass productivity, and biochemical composition of biomass with cultivations in standard Bold basal medium (UTEX, [s.d.]).

\section{Methodology}

\section{Microorganism}

In this study, Chlorella vulgaris (CCMA-UFSCar 689) was employed. It was isolated at the Juréia Itatins Ecological Park (Peruíbe City, São Paulo State) (Matsudo et al., 2020), and kept in Erlenmeyer flasks containing Bold basal medium (UTEX, [s.d.]).

For preparing the inoculum, a small part of the cell suspension was aseptically added to other Erlenmeyer flasks containing the same sterile culture medium. The microorganism was kept in batch-type cultures, under light intensity of approximately $40 \mu \mathrm{mol}$ photons $\mathrm{m}^{-2} \mathrm{~s}^{-1}$, temperature of $25^{\circ} \mathrm{C}$, initial $\mathrm{pH}$ of 7.0 , and agitation of $100 \mathrm{RPM}$. The initial biomass concentration was between 50 and $100 \mathrm{mg} \cdot \mathrm{L}^{-1}$. 
Tubular photobioreactor and culture conditions

The photobioreactor was built in the laboratory (Rodrigues-Sousa et al., 2021), adapting the one described by Ferreira et al. (2012), consisting of 20 transparent glass tubes $(50 \mathrm{~cm}$ long and $1 \mathrm{~cm}$ internal diameter), with $2 \%$ inclination $\left(1.15^{\circ}\right)$ to facilitate the liquid flow, interconnected with silicone hoses of the same internal diameter. The illuminated volume corresponds to $1.26 \mathrm{~L}$, and the total volume of the system was $2 \mathrm{~L}$. There is a T-shaped tube in the lower part of the reactor tubes, in which compressed air enters to move the cell suspension into a flask on the top. In this flask, a porous stone is attached to a hose with an internal diameter of $4 \mathrm{~mm}$, in which $\mathrm{CO}_{2}$ enters to maintain $\mathrm{pH}$ when the solenoid valve opens, controlled by a programmed timer. Fluorescent lamps of 18 Watts were used to provide light at the intensity of $40 \mu \mathrm{mol}$ photons $\mathrm{m}^{-2} \mathrm{~s}^{-1}$.

Secondary wastewater from a dairy industry located in Southern Minas Gerais State was used. This wastewater results from primary treatment (with sieve and grease traps) and secondary treatment, carried out by the industry itself, through stabilization ponds (one anaerobic pond and two facultative ponds). In the laboratory, wastewater was filtered and frozen until it was used to not lose its original characteristics.

Different dilutions of secondary wastewater with distilled water were evaluated, obtaining the ratios 1:3 (25\%), 1:1 (50\%), and 3:1 (75\%). These cultures were compared with those carried out in secondary wastewater without dilution (100\%) and Bold basal medium (control).

Since a low concentration of total nitrogen was detected in the wastewater, and considering the concentration of residual phosphate, supplementation of this nutrient was carried out, in the form of sodium nitrate, to obtain the same proportion $(\mathrm{N}: \mathrm{P})$ present in the Bold medium.

\section{Analytical methodologies}

\section{Determining biomass concentration}

Biomass concentration was determined by turbidimetry at $550 \mathrm{~nm}$ (Becker, 2004). To do so, a calibration curve was constructed, correlating absorbance $(550 \mathrm{~nm})$ and biomass concentration (dry mass). Dry mass was gravimetrically determined in filters with a pore diameter of $1.2 \mu \mathrm{m}$.

\section{Nutrients and chemical oxygen demand analyses}

Both the Bold basal medium and secondary wastewater from the dairy industry were submitted to the following nutrient analyses, before and after cultivation: total inorganic nitrogen (nitrate, nitrite, and ammonium) and phosphate. For such analyses, the samples were previously filtered through a glass fiber membrane $(0.45 \mu \mathrm{m})$ to remove organic matter.

Nitrogen in the form of nitrate was quantified by spectrophotometric method, according to APHA (2005). After acidification with $\mathrm{HCl}$, to avoid interference with $\mathrm{CaCO}_{3}$ concentrations, the samples were subjected to absorbance measurements at $200 \mathrm{~nm}$, subtracting the absorbance values at $275 \mathrm{~nm}$ (interference from organic matter). A calibration curve was drawn up using $\mathrm{KNO}_{3}$.

Nitrogen in the form of nitrite was quantified according to Mackereth et al. (1978) and Carmouze (1994). It is a spectrophotometric method that involves reacting the nitrite with $\mathrm{C}_{6} \mathrm{H}_{8} \mathrm{O}_{2} \mathrm{~N}_{2} \mathrm{~S}$ and $\mathrm{C}_{12} \mathrm{H}_{14} \mathrm{~N}_{2} \cdot 2 \mathrm{HCl}$ in an acid medium. The absorbance is measured with at $543 \mathrm{~nm}$, and the calibration curve was drawn up with $\mathrm{KNO}_{2}$.

Ammonium concentration was obtained by a spectrophotometric method involving the Berthelot reaction, using phenol and dichloroisocyanuric acid. Absorbance was measured at $630 \mathrm{~nm}$, and $\mathrm{NH}_{4} \mathrm{Cl}$ was used to draw up the calibration curve (Koroleff, 1976; Carmouze, 1994).

Phosphate was also quantified by spectrophotometric method, involving reaction with $\left(\mathrm{NH}_{4}\right)_{8} \mathrm{Mo}_{7} \mathrm{O}_{24} 4 \mathrm{H}_{2} \mathrm{O}, \mathrm{K}_{2} \mathrm{Sb}_{2}\left(\mathrm{C}_{4} \mathrm{H}_{2} \mathrm{O}_{6}\right)_{2}$, and $\mathrm{C}_{6} \mathrm{H}_{8} \mathrm{O}_{8}$ in acid medium. Absorbance is measured at $885 \mathrm{~nm}$, and solutions with different concentrations of $\mathrm{KH}_{2} \mathrm{PO}_{4}$ were used for the calibration curve (Strickland and Parsons, 1960; Carmouze, 1994).

Secondary wastewater from the dairy industry was also submitted to COD (chemical oxygen demand) analysis by colorimetric method, using potassium dichromate as an oxidative agent, in accordance with the Standard methods for the examination of water and wastewater (APHA, 2005).

\section{Analysis of the biochemical composition of biomass}

At the end of each cultivation, the resulting biomass was centrifuged and dried at $60^{\circ} \mathrm{C}$ for approximately 12 hours. The pulverized dry biomass was submitted to the determination of total lipids and total proteins. Then, the lipid fraction was submitted to the analysis of fatty acids profile.

The quantification of total proteins was performed by the classic Kjeldahl method, adopting 6.25 as conversion factor based on the total nitrogen content (AOAC, 1984).

The quantification of total lipids was performed by the Soxhlet methodology, based on extraction with organic solvent (Chloroform:Methanol; 2:1 v/v) (Pelizer et al., 1999).

Finally, the lipid fraction was recovered in petroleum ether. After the conversion of fatty acids into their corresponding methyl esters (Hartman and Lago, 1973), the analysis of fatty acid methyl esters was carried out in a gas chromatograph, model 7890 (Agillent Technologies, USA), equipped with a split/splitless injector and FID detector (flame ionization detector) in accordance with Pérez-Mora et al. (2016). The identification of fatty acids in the samples was carried out by comparing the retention times with those obtained in standards present in " 37 Component FAME Mix" (Supelco).

\section{Data analysis}

Cultures were evaluated in terms of maximum biomass concentration $(\mathrm{Xm})$, and this data was considered to calculate biomass productivity $(\mathrm{Px})$, according to Equation 1 : 


$$
P x=\frac{X m-X i}{\mathrm{t}}
$$

In which:

$\mathrm{Xi}=$ the initial biomass concentration;

$\mathrm{t}=$ the cultivation time.

Such data, as well as the lipid and protein contents, were compared by analysis of variance (ANOVA), with a significance level of 0.05 , and Tukey's test, using the software Minitab 17.

\section{Results and Discussion}

Cultivation of Chlorella vulgaris in a tubular photobioreactor

In microalgae biomass production, the culture medium's choice is extremely important, combining low cost and adequate conditions for growth and obtaining the biochemical composition of interest. In the present work, the use of secondary wastewater from the dairy industry was evaluated in different ratios with distilled water: 1:3 (25\%), 1:1 (50\%), and 3:1 (75\%). Wastewater was also used without dilution (100\%), and cultivation in Bold basal medium was carried out as control.

When analyzing the concentrations of nitrogen and phosphorus in secondary wastewater from the dairy industry, the concentration of phosphorus (in the form of phosphate) was equal to $14 \mathrm{mg}$. $\mathrm{L}^{-1}$. In contrast, the total inorganic nitrogen concentration (sum of nitrogen in the forms of nitrate, nitrite, and ammonium) was lower than $1 \mathrm{mg} \cdot \mathrm{L}^{-1}$. Thus, wastewater was supplemented to maintain the same nitrogen/ phosphorus ratio as the Bold medium, which is 0.77 . That is, $10 \mathrm{mg} . \mathrm{L}^{-1}$ of nitrogen in the form of $\mathrm{NaNO}_{3}$ was added. Regardless of dilution, all cultures with wastewater had the same initial supplementation with the nitrogen source.

Table 1 presents the results of maximum cell concentration $(\mathrm{Xm})$, and biomass productivity $(\mathrm{Px})$ obtained in the four different conditions using wastewater, as well as in the standard culture, using the Bold basal medium. Figure 1 shows the average growth curves (resulting from

Table 1 - Maximum Biomass Concentration (Xm) and Biomass Productivity $(\mathrm{Px})$ for Chlorella vulgaris cultures in wastewater from the dairy industry

\begin{tabular}{|l|c|c|}
\hline Run & $\mathbf{X} \mathbf{m}^{\star}\left(\mathbf{m g} \cdot \mathbf{L}^{-1}\right)$ & $\mathbf{P x}^{\star}\left(\mathbf{m g} \cdot \mathbf{L}^{-1} \cdot \mathbf{d}^{-1}\right)$ \\
\hline Control (Bold) & $970.60 \pm 48.90^{\mathrm{A}}$ & $112.70 \pm 8.54^{\mathrm{A}}$ \\
\hline Wastewater 25\% & $224.30 \pm 77.90^{\mathrm{C}}$ & $36.40 \pm 15.60^{\mathrm{B}}$ \\
\hline Wastewater 50\% & $545.70 \pm 63.70^{\mathrm{BC}}$ & $114.79 \pm 6.21^{\mathrm{A}}$ \\
\hline Wastewater 75\% & $667.20 \pm 126.00^{\mathrm{AB}}$ & $126.16 \pm 5.60^{\mathrm{A}}$ \\
\hline Wastewater 100\% & $742.60 \pm 114.60^{\mathrm{AB}}$ & $92.58 \pm 1.16^{\mathrm{A}}$ \\
\hline
\end{tabular}

${ }^{\star}$ Average value obtained by the duplicate; ${ }^{\mathrm{A}, \mathrm{B}}$ equal letters do not differ statistically, according to Tukey's test, considering a 95\% confidence interval for Xm and Px. tests in duplicates) obtained for the four cultures in wastewater and compared with the standard Bold medium (control).

After analyzing Table 1 and Figure 1, the growth of microalgae was found to occur satisfactorily in wastewater, even with the lowest concentration of nutrients, especially nitrogen and phosphorus $(\mathrm{N}=41.17$ mg. $\mathrm{L}^{-1}$ and $10 \mathrm{mg} . \mathrm{L}^{-1}$ and $\mathrm{P}=53.25 \mathrm{mg} . \mathrm{L}^{-1}$ and $14 \mathrm{mg} . \mathrm{L}^{-1}$, in the Bold basal medium and the wastewater, respectively).

However, the highest dilutions (Wastewater 25\% and Wastewater $50 \%)$ led to a reduction in the maximum biomass concentration $\left(\mathrm{Xm}=224.30\right.$ and $545.70 \mathrm{mg} . \mathrm{L}^{-1}$, respectively), which was lower than the values obtained in the control culture $\left(\mathrm{Xm}=970.60 \mathrm{mg} \cdot \mathrm{L}^{-1}\right)$ and in the wastewater without dilution $\left(\mathrm{Xm}=742.60 \mathrm{mg} . \mathrm{L}^{-1}\right)$. The analysis of variance (ANOVA) confirms that the different experimental conditions significantly influenced this parameter $(p=0.004)$.

Despite the lower concentration of inorganic nutrients dissolved in wastewater, compared with the Bold basal medium, satisfactory microbial growth was probably benefited by the presence of organic compounds, since the COD (chemical oxygen demand) analysis resulted in $524 \mathrm{mg}$. $\mathrm{O}_{2} \cdot \mathrm{L}^{-1}$. This organic compounds promoted the mixotrophic metabolism of C. vulgaris, which allows the reduction of biomass loss during respiration, increasing productivity (Yeh and Chang, 2012; Safi et al., 2014).

Experimental conditions also significantly influenced biomass productivity (ANOVA, $\mathrm{p}=0.001$ ). In fact, only the highest dilution led to a reduction in this parameter $\left(\mathrm{Px}=36.40 \mathrm{mg} \cdot \mathrm{L}^{-1} \cdot \mathrm{d}^{-1}\right)$. Although the $50 \%$ wastewater culture resulted in significantly lower biomass concentration (compared with the control culture), the shorter cultivation time resulted in statistically similar $\mathrm{Px}\left(\mathrm{Px}=112.70\right.$ and $114.79 \mathrm{mg} \cdot \mathrm{L}^{-1} \cdot \mathrm{d}^{-1}$, for control and Wastewater 50\%, respectively). As shown in Figure 1, in Wastewater $100 \%$ and Control, growth stabilization started on days 7 or 8 . In other cultures (diluted wastewaters), this stabilization started between the $4^{\text {th }}$ and $6^{\text {th }}$ days of cultivation.

Therefore, the use of wastewater $100 \%$ (without dilution) is recommended, avoiding the increase in volume and reducing water use for dilution. Kothari et al. (2012) suggest using Wastewater $75 \%$ to cultivate Chlorella pyrenoidosa. Tests carried out in our laboratory (Rodrigues-Sousa et al., 2021) show that in the cultivation using Erlenmeyer flasks, undiluted wastewater (Wastewater 100\%) leads to a faster $\mathrm{pH}$ increase, inhibiting microalgae growth. In the present work, however, in a tubular photobioreactor, $\mathrm{pH}$ control with automated addition of pure $\mathrm{CO}_{2}$ was probably the factor that favored the growth of Chlorella vulgaris even in undiluted wastewater.

Another factor to be highlighted here is nitrogen supplementation efficiency (in the form of $\mathrm{NaNO}_{3}$ ) to guarantee the $\mathrm{N}: \mathrm{P}$ ratio present in the Bold basal medium ( $\mathrm{N}: \mathrm{P}=0.77)$. McGinn et al. (2011) point out that when growth is limited by a certain nutrient, the consequence is a decrease in the absorption of others. Therefore, the the medium components ratio can interfere in the yield of cultures, biomass biochemical composition, and the accumulation of certain nutrients in the extracellular medium. 


\section{Nutrient analysis}

Nutrient analyses were carried out to verify the consumption of inorganic nutrients, total inorganic nitrogen (sum of nitrogen in the forms of nitrate, nitrite, and ammonium), and phosphorus (in the form of phosphate) after the cultivation as a way of tertiary treatment of industrial wastewater. It enabled calculating the efficiency of these nutrients' consumptions in each culture. The results of total inorganic nitrogen analyses for the cultures are shown in Table 2 , and the results of the phosphorus analyses are shown in Table 3.

The results presented in Table 2 show a satisfactory efficiency in terms of total inorganic nitrogen consumption in all cultivation with wastewater with respect to the control, all of which have consumption efficiency of 96 to $98 \%$. This efficiency in the consumption of total nitrogen is of great interest for wastewater tertiary treatment.

Through the results presented in Table 3, a high efficiency also in the removal of phosphorus in those cultures using wastewater supplemented with nitrogen can be observed, which occurs due to the low initial concentration of this nutrient in these media, when compared to the concentration found in the standard medium.

Similar results are obtained in the cultivation of Botryococcus braunii in diluted (50\%) livestock wastewater, a condition in which the microalgae removed, on average, $88 \%$ of total nitrogen and $98 \%$ of total phosphorus (Shen et al., 2008).

Based on these results, wastewater after cultivation of the microalgae Chlorella vulgaris could be discharged in bodies of water, since NT values were in accordance with CONAMA resolution 357/2005, which states that - for freshwater from classes 1 and 2, in which nitrogen is a limiting factor for eutrophication, under the conditions established by the competent environmental agency - the total nitrogen value (after oxidation) should not exceed $1.27 \mathrm{mg} . \mathrm{L}^{-1}$ for lentic environments and $2.18 \mathrm{mg} \cdot \mathrm{L}^{-1}$ for

Table 2 - Total inorganic nitrogen concentration values at the beginning and end of all cultures, besides their consumption efficiency

\begin{tabular}{|l|c|c|c|}
\multirow{2}{*}{ Medium } & \multicolumn{3}{|c}{ Total nitrogen } \\
\cline { 2 - 4 } & Initial (mg.L-1) & Final (mg.L $\left.\mathbf{m}^{-1}\right)$ & Efficiency \\
\hline Control (Bold) & 65.25 & $2.32 \pm 0.35$ & $96 \%$ \\
\hline Wastewater 25\% & $23.88 \pm 12.66$ & $0.33 \pm 0.03$ & $98 \%$ \\
\hline Wastewater 50\% & $23.88 \pm 12.66$ & $0.58 \pm 0.16$ & $97 \%$ \\
\hline Wastewater 75\% & $23.88 \pm 12.66$ & $0.49 \pm 0.11$ & $97 \%$ \\
\hline Wastewater 100\% & $23.88 \pm 12.66$ & $0.92 \pm 0.03$ & $96 \%$ \\
\hline
\end{tabular}

Table 3 - Initial and final values of phosphorus concentration and the efficiency of its consumption in all cultures

\begin{tabular}{|l|c|c|c|}
\hline \multirow{2}{*}{ Medium } & \multicolumn{3}{|c|}{ Phosphorus } \\
\cline { 2 - 4 } Control (Bold) & Initial (mg.L L $\left.^{-1}\right)$ & Final (mg.L & Efficiency \\
\hline Wastewater 25\% & 113.10 & $84.98 \pm 7.06$ & $25 \%$ \\
\hline Wastewater 50\% & 3.50 & $0.02 \pm 0.02$ & $99 \%$ \\
\hline Wastewater 75\% & 10.00 & $0.05 \pm 0.03$ & $99 \%$ \\
\hline Wastewater 100\% & 14.00 & $0.23 \pm 0.21$ & $97 \%$ \\
\hline
\end{tabular}

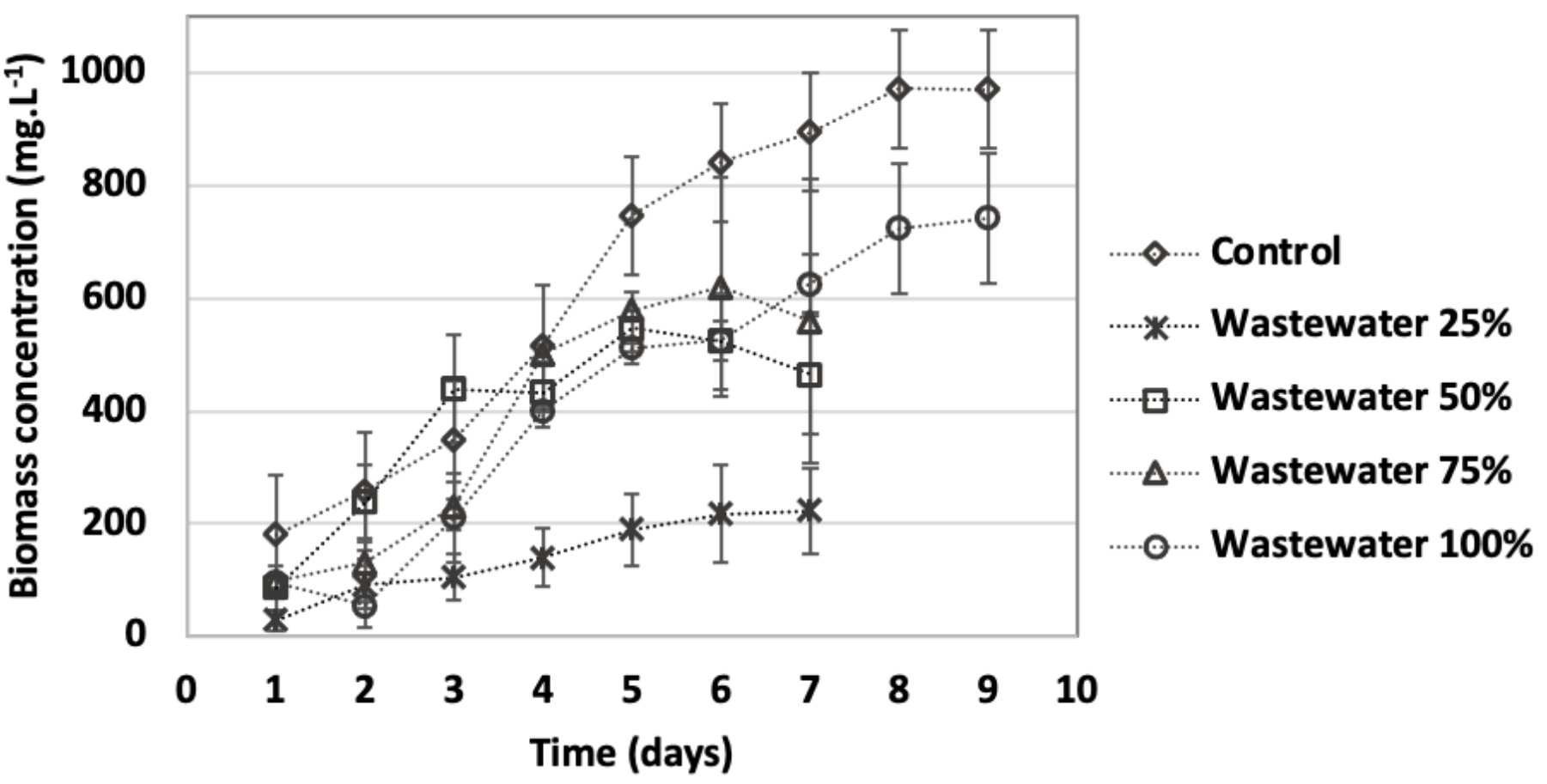

Figure 1 - Average growth curves for Chlorella vulgaris cultures in different proportions of wastewater from the dairy industry 
lotic environments at the reference stream flow. Nonetheless, if only the concentration of phosphorus is considered, no wastewater could be discharged into a lentic water body, since the resolution establishes for these class 1 and 2 environments that the total phosphorus value should be less than $0.020 \mathrm{mg} . \mathrm{L}^{-1} \mathrm{P}$, but this treated wastewater could be discharged in lotic and tributary streams (of intermediate environments), since the total $\mathrm{P}$ value, in this case, must be less than $0.1 \mathrm{mg} . \mathrm{L}^{-1} \mathrm{P}$ (Brasil, 2005).

Considering that microalgae can effectively grow in waters containing nitrate and phosphate and also accumulate nutrients and metals from wastewaters, these attributes make them attractive and efficient tools beneficial to the environment, allowing wastewater treatment at a low cost (Kothari et al., 2012).

\section{Analysis of the biochemical composition of biomass}

The choice of a suitable medium is extremely important, since, in addition to its composition influencing the growth rate, it can also influence the biochemical composition of microalgae, which may favor certain later biomass applications (Lourenço, 2006). Thus, the biomass obtained in the cultures were subjected to analyses of total lipids and total proteins (Table 4 ), and fatty acid profile (Table 5 ).

Table 4 shows that the lipid content varied from 38.45 to $43.85 \%$. According to ANOVA, there was no statistically significant influence between different culture conditions on this dependent variable

Table 4 - Content of lipids and proteins in Chlorella vulgaris biomass grown in dairy industry wastewater

\begin{tabular}{|l|c|c|}
\hline Medium & Lipids (\%) & Proteins (\%) \\
\hline Control (Bold) & $38.45 \pm 0.73^{\mathrm{A}}$ & $13.05 \pm 2.80^{\mathrm{A}}$ \\
\hline Wastewater 25\% Supplemented & $39.04 \pm 9.20^{\mathrm{A}}$ & $12.95 \pm 3.32^{\mathrm{A}}$ \\
\hline Wastewater 50\% Supplemented & $39.76 \pm 9.92^{\mathrm{A}}$ & $14.16 \pm 2.31^{\mathrm{A}}$ \\
\hline Wastewater 75\% Supplemented & $38.56 \pm 9.81^{\mathrm{A}}$ & $11.71 \pm 0.64^{\mathrm{A}}$ \\
\hline Wastewater 100\% Supplemented & $43.85 \pm 4.47^{\mathrm{A}}$ & $11.73 \pm 0.50^{\mathrm{A}}$ \\
\hline
\end{tabular}

$(\mathrm{p}=0.945)$. Several authors state that it is possible to manipulate culture conditions to alter the biochemical composition of biomass, for example, by increasing the lipid content. Regarding lipids, their increase could be induced by the addition of sodium thiosulfate (reducing agent), osmotic stress (by the addition of $\mathrm{NaCl}$, for instance), or nutritional stress (nitrogen starvation, for instance) (Takagi et al., 2006; Avila-León et al., 2020; Rodrigues-Sousa et al., 2021). The values found herein are quite promising, if comparing with data obtained with $\mathrm{Bo}$ tryococcus braunii biomass (32.6 36.9\%) (Pérez-Mora et al., 2016) and Ankistrodesmus braunii biomass (38 39\%) (Bresaola et al., 2019).

Moreover, concerning the protein content, the different conditions of the culture medium did not significantly influence this parameter (ANOVA, $p=0.784$ ), with mean values between 11.71 and $14.16 \%$. These reduced values of total proteins can be justified by the low residual value of nitrogen, which is of great importance for the biosynthesis of amino acids and, consequently, of proteins (Markou et al., 2014); the stress caused by the lack of this nutrient may have induced the accumulation of lipids and the reduction of protein content (Wang et al., 2011). If the objective is obtaining biomass with high protein content, supplementing nitrogen throughout cultivation would be possible, as it has been well observed by different studies cultivating microalgae or cyanobacteria (Matsudo et al., 2009; Carvalho et al., 2013; Bresaola et al., 2019).

Under unfavorable or stressful environmental conditions, many algae alter their biosynthetic pathways to form and accumulate lipids, especially in the form of triacylglycerols, which serve mainly as carbon and energy storage. The fatty acid composition of typical microalgae oil is mainly composed of a mixture of unsaturated fatty acids, such as palmitoleic (16:1), oleic (18:1), linoleic (18:2), and linolenic (18:3) (Khan et al., 2009).

Table 5 shows that saturated fatty acids, such as palmitic (16:0) and stearic (C18:0), and unsaturated fatty acids, such as palmitoleic (16:1), heptadecenoic (17:1), oleic (C18:1n9), linoleic (C18:2n6), and $\gamma$-linolenic (C18:3n6) were present in all cultivation conditions of Chlorella vulgaris. Palmitic (16:0) and oleic (C18:1n9) acids had the highest per-

Table 5 - Fatty Acids Profile (\%) of Chlorella vulgaris grown in wastewater from the dairy industry

\begin{tabular}{|l|c|c|c|c|c|}
\hline Fatty acid (\%) & Control & Wastewater 25\% & Wastewater 50\% & Wastewater 75\% & Wastewater 100\% \\
\hline C16:0 & $30.45 \pm 0.31$ & $36.55 \pm 5.21$ & $30.78 \pm 0.14$ & $31.21 \pm 5.20$ & $31.60 \pm 0.31$ \\
\hline C16:1 & $1.74 \pm 0.13$ & $0.81 \pm 0.25$ & $0.88 \pm 0.07$ & $1.24 \pm 0.12$ & $0.86 \pm 0.02$ \\
\hline N.I. ${ }^{*}$ & $1.93 \pm 0.09$ & $1.09 \pm 0.25$ & $0.69 \pm 0.05$ & $0.36 \pm 0.00$ & $0.74 \pm 0.08$ \\
\hline C17:1 & $3.22 \pm 0.13$ & $2.65 \pm 0.59$ & $2.33 \pm 0.33$ & $3.72 \pm 0.90$ & $2.50 \pm 0.11$ \\
\hline N.I. ${ }^{*}$ & $1.42 \pm 0.05$ & $1.44 \pm 0.91$ & $2.55 \pm 0.23$ & $3.63 \pm 1.23$ & $2.39 \pm 0.11$ \\
\hline C18:0 & $3.12 \pm 0.09$ & $4.03 \pm 0.91$ & $2.98 \pm 0.15$ & $5.06 \pm 3.95$ & $4.15 \pm 0.12$ \\
\hline C18:1n9 & $38.54 \pm 0.40$ & $37.66 \pm 13.44$ & $39.22 \pm 1.69$ & $28.60 \pm 0.50$ & $37.13 \pm 0.55$ \\
\hline C18:2n6 & $9.80 \pm 0.04$ & $8.90 \pm 2.77$ & $7.98 \pm 0.21$ & $10.35 \pm 1.29$ \\
\hline C18:3n6 & $9.57 \pm 0.32$ & $9.60 \pm 2.13$ & $12.68 \pm 0.78$ & $16.18 \pm 5.47$ \\
\hline
\end{tabular}

${ }^{\star}$ Percentage of fatty acids in relation to the total content (mass/mass); ${ }^{* *}$ unidentified compound, absent in the standard $37 \mathrm{FAME}$ mix; C16:0 palmitic acid; C16:1 palmitoleic acid; C17:1 cis-10-heptadecenoic acid; C18:0 stearic acid; C18:1n9 oleic acid; C18:2n6 linoleic acid; C18:3n6 $\gamma$-linolenic acid. 
centage in all cultures (30 36\% and $27 \sim 39 \%$, respectively), which agrees with results obtained by Converti et al. (2009).

Linoleic acid (C18:2n6c), considered essential for the human organism (Teitelbaum; Walker, 2001), was also detected in all cultures, reaching values between 7.89 and $10.35 \%$. Finally, $\gamma$-linolenic acid (C18:3n6) was present with values between 9.57 and $16.18 \%$. The importance of these two fatty acids ( $\gamma$-linolenic acid and linoleic acid) is justified because they are precursors of arachidonic acid (Verlengia and Lima, 2002) and can, therefore, serve in the production of fatty acid supplements (Tallima and El Ridi, 2018).

Biodiesel is currently produced from oilseed plants (soy, rapeseed, and palm), but microalgae are presented as sustainable alternative feedstock for its production. Fatty acids methyl esters represent the main component of biodiesel, and the chemical structure of these molecules has a strong influence on the properties of this fuel ( $\mathrm{Lu}$ et al., 2015). Although high levels of polyunsaturated fatty acids reduce the cold filter plugging point, they also reduce the oxidative stability of the product (Schenk et al., 2008). Therefore, as it can be seen in Table 5, the predominance of palmitic acid (saturated) and oleic acid (monounsaturated) makes the biomass obtained as suitable for this purpose, which was also observed in Chlorella sp. U4341 and Monoraphidium sp. FXY-10 grown in monoculture or co-culture by Zhao et al. (2014).

The biomass of Chlorella vulgaris, produced in the tertiary treatment of dairy industry wastewater, could be mainly employed as source of feedstock for biodiesel and animal feed production (Rodrigues-Sousa et al., 2021). Therefore, besides helping to mitigate an environmental problem (eutrophication), the use of Chlorella vulgaris in the tertiary treatment of dairy industry wastewater could allow reducing the costs to produce biomass for bioenergy and animal feed, serving as an alternative source, mainly during extreme dry seasons.

\section{Conclusions}

Microalgae can be an excellent solution for the tertiary treatment of dairy industry wastewater, allowing to minimize environmental problems, such as eutrophication, and generating biomass for the extraction of oils, bioactive compounds, as well as proteins and carbohydrates for animal feed.

When using secondary wastewater from a dairy industry, there was no need for dilution, as long as $\mathrm{CO}_{2}$ wass added for $\mathrm{pH}$ control, reaching values of maximum biomass concentration and biomass productivity similar to control culture in Bold basal medium. However, quantifying phosphorus and nitrogen levels, and supplement in case of lacking one of them is important, adjusting the proportion similar to that found in the Bold basal medium ( $\mathrm{N}: \mathrm{P}=0.77)$.

These results are promising in a Brazilian state where the dairy industry is of great economic and social importance. Besides their environmental benefits, the different biomass applications could bring economic benefits, even serving as an input (including proteins) for animal feed, for example.

\section{Contribution of authors:}

Nunes, I.V.O.: Investigation, methodology, formal analysis, writing - original draft. Inoue, C.H.B.: Investigation, methodology, writing - review and editing. Sousa, A.E.R.: Investigation, methodology. Carvalho, J.C.M.: Conceptualization, resources, funding acquisition, visualization. Gomes, A.M.A.: Methodology, visualization, writing - review and editing; Matsudo, M.C.: Conceptualization, funding acquisition, supervision, project administration, writing - review and editing.

\section{References}

American Public Health Association (APHA). 2005. Standard methods for the examination of water and wastewater. 21st. ed. American Public Health Association, Washington, D.C.

Association of Official Analytical Chemists (AOAC). 1984. Official Methods of Analysis of the Association of Official Analytical Chemists. 14th. ed. American Public Health Association, Arlington.

Avila-León, I.A.; Matsudo, M.C.; Ferreira-Camargo, L.S.; Rodrigues-Ract, J.N.; Carvalho, J.C.M., 2020. Evaluation of Neochloris oleoabundans as sustainable source of oil-rich biomass. Brazilian Journal of Chemical Engineering, v. 37, 41-48. https://doi.org/10.1007/s43153-020-00011-3.

Barreto, L.V.; Barros, F.M.; Bonomo, P.; Rocha, F.A.; Amorim, J.S., 2013. Eutrofização em rios brasileiros. Enciclopédia Biosfera, Centro Científico Conhecer, v. 9, (16), 2165-2179.

Becker, W., 2004. Microalgae in human and animal nutrition. In: Richmond, A. (Ed.), Handbook of microalgal culture: biotechnology and applied phycology. Blackwell Science, London, pp. 312-351.
Bellucci, M.; Marazzi, F.; Naddeo, L.S.; Piergiacomo, F.; Beneduce, L.; Ficara, E.; Mezzanotte, V., 2020. Disinfection and nutrient removal in laboratory-scale photobioreactors for wastewater tertiary treatment. Journal of Chemical Technology and Biotechnology, v. 95, (4), 959-966. https://doi.org/10.1002/jctb.6010.

Borowitzka, M.A., 1999. Commercial production of microalgae: ponds, tanks, and fermenters. Progress in Industrial Microbiology, v. 35, 313-321. https:// doi.org/10.1016/S0079-6352(99)80123-4.

Brasil. 2005. Resolução no 357, de 18 de março de 2005. Dispõe sobre a classificação dos corpos de água e diretrizes ambientais para o seu enquadramento, bem como estabelece as condições e padrões de lançamento de efluentes, e dá outras providências (Accessed in September, 2007) at: http:// www.mma.gov.br/port/conama/legiabre.cfm?codlegi=459.

Bresaola, M.D.; Morocho-Jácome, A.L.; Matsudo, M.C.; Carvalho, J.C.M., 2019. Semi-continuous process as a promising technique in Ankistrodesmus braunii cultivation in photobioreactor. Journal of Applied Phycology, v. 31, (4), 2197-2205. https://doi.org/10.1007/s10811-019-01774-0. 
Carmouze, J.P., 1994. O metabolismo dos ecossistemas aquáticos: fundamentos teóricos, métodos de estudo e análises químicas. Edgard Blucher, São Paulo.

Carvalho, J.C.M.; Bezerra, R.P.; Matsudo, M.C.; Sato, S., 2013. Cultivation of Arthrospira (Spirulina) platensis by Fed-Batch Process. In: Lee, J. (Ed.), Advanced Biofuels and Bioproducts. Springer New York, 2013. v. 9781461433. pp. 781-805. https://doi.org/10.1007/978-1-4614-3348-4_33.

Carvalho, J.C.M.; Matsudo, M.C.; Bezerra, R.P.; Ferreira-Camargo, L.S.; Sato, S., 2014. Microalgae bioreactors. In: Bajpai, R.; Prokop, A.; Zappi, M. (Eds.), Algal Biorefineries: Volume 1: Cultivation of Cells and Products. Springer, Dordrecht, pp. 83-126. https://doi.org/10.1007/978-94-007-7494-0_4.

Chinnasamy, S.; Bhatnagar, A.; Hunt, R.W.; Das, K.C., 2010. Microalgae cultivation in a wastewater dominated by carpet mill effluents for biofuel applications. Bioresource Technology, v. 101, (9), 3097-3105. https://doi. org/10.1016/j.biortech.2009.12.026.

Choi, Y.K.; Jang, H.M.; Kan, E., 2018. Microalgal Biomass and Lipid Production on Dairy Effluent Using a Novel Microalga, Chlorella sp. Isolated from Dairy Wastewater. Biotechnology and Bioprocess Engineering, v. 23, (3), 333-340. https://doi.org/10.1007/s12257-018-0094-y.

Companhia Nacional de Abastecimento (CONAB). 2018. Leite e derivados (Accessed in March, 2020) at: https://www.conab.gov.br/info-agro/analises-domercado-agropecuario-e-extrativista/analises-do-mercado.

Converti, A.; Casazza, A.A.; Ortiz, E.Y.; Perego, P.; Borghi, M., 2009. Effect of temperature and nitrogen concentration on the growth and lipid content of Nannochloropsis oculata and Chlorella vulgaris for biodiesel production. Chemical Engineering and Processing: Process Intensification, v. 48, (6), 11461151. https://doi.org/10.1016/j.cep.2009.03.006.

Derner, R.B.; Ohse, S.; Villela, M.; Carvalho, S.M.; Fett, R., 2006. Microalgae, products and applications. Ciência Rural, v. 36, (6), 1959-1967. https://doi. org/10.1590/S0103-84782006000600050.

Empresa Brasileira de Pesquisa Agropecuária (EMBRAPA). 2018. Leite oportunidades. Texto Comunicação Corporativa, São Paulo (Accessed in March, 2020) at: www.embrapa.br/gado-de-leite.

Ferreira, L.S.; Rodrigues, M.S.; Converti, A.; Sato, S.; Carvalho, J.C.M., 2012. Arthrospira (Spirulina) platensis cultivation in tubular photobioreactor: Use of no-cost CO2from ethanol fermentation. Applied Energy, v. 92, 379-385. http:// dx.doi.org/10.1016/j.apenergy.2011.11.019.

Gupta, P.L.; Lee, S.M.; Choi, H.J., 2016. Integration of microalgal cultivation system for wastewater remediation and sustainable biomass production. World Journal of Microbiology and Biotechnology, v. 32, 139. https://doi.org/10.1007/ s11274-016-2090-8.

Hartman, L.; Lago, R.C., 1973. Rapid preparation of fatty acid methyl esters from lipids. Laboratory Practice, v. 22, (6), 475-477.

Khan, S.A.; Rashmi; Hussain, M.Z.; Prasad, S.; Banerjee, U.C., 2009. Prospects of biodiesel production from microalgae in India. Renewable and Sustainable Energy Reviews, v. 13, (9), 2361-2372. https://doi.org/10.1016/j.rser.2009.04.005.

Koroleff, F., 1976. Determination of nutrients. In: Grasshoff, K. (Ed.), Methods of seawater analysis. Verlag Chemie, Weinheim, pp. 117-181.

Kothari, R.; Pathak, V.V.; Kumar, V.; Singh, D.P., 2012. Experimental study for growth potential of unicellular alga Chlorella pyrenoidosa on dairy waste water: An integrated approach for treatment and biofuel production. Bioresource Technology, v. 116, 466-470. http://dx.doi.org/10.1016/j.biortech.2012.03.121.

Kothari, R.; Prasad, R.; Kumar, V.; Singh, D.P., 2013. Production of biodiesel from microalgae Chlamydomonas polypyrenoideum grown on dairy industry wastewater. Bioresource Technology, v. 144, 499-503. http://dx.doi. org/10.1016/j.biortech.2013.06.116.
Lourenço, S.O., 2006. Cultivo de microalgas marinhas: princípios e aplicações. Rima, São Carlos.

Lu, W.; Wang, Z.; Wang, X.; Yuan, Z., 2015. Cultivation of Chlorella sp. using raw diary wastewater for nutrient removal and biodiesel production: Characteristics comparison of indoor bench-scale and outdoor pilot-scale cultures. Bioresource Technology, v. 192, 382-388. http://dx.doi.org/10.1016/j. biortech.2015.05.094.

Machado, R.M.G.; Silva, P.C.; Freire, V.H., 2001. Controle ambiental em indústrias de laticínios. Brasil Alimentos, (7), 34-36.

Mackereth, F.J.; Heron, J.; Talling, J.F., 1978. Water analysis: some revised methods for limnologists. Freshwater Biological Association, Ambleside.

Maganha, M.F.B. 2006. Guia técnico ambiental da indústria de produtos lácteos. CETESB, São Paulo.

Markou, G.; Vandamme, D.; Muylaert, K, 2014. Microalgal and cyanobacterial cultivation: The supply of nutrients. Water Research, v. 65, 186-202. http:// dx.doi.org/10.1016/j.watres.2014.07.025

Mata, T.M.; Martins, A.A.; Caetano, N.S., 2010. Microalgae for biodiesel production and other applications: A review. Renewable and Sustainable Energy Reviews, v. 14, (1), 217-232. http://dx.doi.org/10.1016/j. rser.2009.07.020

Matsudo, M.C.; Bezerra, R.P.; Sato, S.; Perego, P.; Converti, A.; Carvalho, J.C.M., 2009. Repeated fed-batch cultivation of Arthrospira (Spirulina) platensis using urea as nitrogen source. Biochemical Engineering Journal, v. 43, (1), 52-57. https://doi.org/10.1016/j.bej.2008.08.009.

Matsudo, M.C.; Sant'Anna, C.L.; Pérez-Mora, L.S.; Silva, R.C.; Carvalho, J.C.M, 2020. Isolation and Evaluation of Microalgae from Mangrove Area in South Coast of Sao Paulo (Brazil) for Lipid Production. International Journal of Current Microbiology and Applied Sciences, v. 9, (6), 1293-1302. https://doi. org/10.20546/ijcmas.2020.906.161.

McGinn, P.J.; Dickinson, K.E.; Bhatti, S.; Frigon, J.C.; Guiot, S.R.; O’Leary, S.J.B., 2011. Integration of microalgae cultivation with industrial waste remediation for biofuel and bioenergy production: Opportunities and limitations. Photosynthesis Research, v. 109, (1-3), 231-247. https://doi. org/10.1007/s11120-011-9638-0.

Pelizer, L.H.; Sassano, C.E.; Carvalho, J.C.M.; Sato, S.; Gioielli, L.A.; Moraes, I.O., 1999. Padronização do método de secagem da biomassa de Spirulina platensis. Farmácia e Química, v. 32, (1), 37-40.

Peng, Y.Y.; Gao, F.; Hang, W.J.W.; Yang, H.L.; Jin, W.H.; Li, C., 2019. Effects of organic matters in domestic wastewater on lipid/carbohydrate production and nutrient removal of Chlorella vulgaris cultivated under mixotrophic growth conditions. Journal of Chemical Technology and Biotechnology, v. 94, (11), 3578-3584. https://doi.org/10.1002/jctb.6161.

Pérez-Mora, L.S.; Matsudo, M.C.; Cezare-Gomes, E.A.; Carvalho, J.C.M., 2016. An investigation into producing Botryococcus braunii in a tubular photobioreactor. Journal of Chemical Technology and Biotechnology, v. 91, (12), 3053-3060. https://doi.org/10.1002/jctb.4934.

Rodrigues-Sousa, A.E.; Nunes, I.V.O.; Muniz-Junior, A.B.; Carvalho, J.C.M.; Mejia-da-Silva, L.C.; Matsudo, M.C., 2021. Nitrogen supplementation for the production of Chlorella vulgaris biomass in secondary effluent from dairy industry. Biochemical Engineering Journal, v. 165, 107818. https://doi. org/10.1016/j.bej.2020.107818.

Safi, C.; Zebib, B.; Merah, O.; Pontalier, P.Y.; Vaca-Garcia, C., 2014. Morphology, composition, production, processing and applications of Chlorella vulgaris: A review. Renewable and Sustainable Energy Reviews, v. 35, 265-278. https://doi.org/10.1016/j.rser.2014.04.007. 
Sarkar, B.; Chakrabarti, P.P.; Vijaykumar, A.; Kale, V., 2006. Wastewater treatment in dairy industries - possibility of reuse. Desalination, v. 195, (1-3), 141-152. https://doi.org/10.1016/j.desal.2005.11.015.

Schenk, P.M.; Thomas-Hall, S.R.; Stephens, E.; Marx, U.C.; Mussgnug, J.H.; Posten, C.; Kruse, O.; Hankamer, B., 2008. Second Generation Biofuels: High-Efficiency Microalgae for Biodiesel Production. BioEnergy Research, v. 1, (1), 20-43. https://doi.org/10.1007/s12155008-9008-8.

Shen, Y.; Yuan, W.; Pei, Z.; Mao, E., 2008. Culture of Microalga Botryococcus in Livestock Wastewater. Transactions of the ASABE, v. 51, (4), 1395-1400. https://doi.org/10.13031/2013.25223.

Sousa, M.P., 2007. Organismos planctônicos de sistemas de lagoas de tratamento de esgotos sanitários como alimento natural na criação de Tilápia do Nilo. Universidade Federal de Viçosa, Viçosa.

Strickland, J.D.; Parsons, T., 1960. A Manual of Seawater Analysis. Bulletin of the Fisheries Research Board of Canada, v. 125, 1-185.

Takagi, M.; Karseno; Yoshida, T. 2006. Effect of Salt Concentration on Intracellular Accumulation of Lipids and Triacylglyceride in Marine Microalgae Dunaliella Cells. Journal of Bioscience and Bioengineering, v. 101, (3), 223-226. https://doi.org/10.1263/jbb.101.223.

Tallima, H.; El Ridi, R., 2018. Arachidonic acid: Physiological roles and potential health benefits - A review. Journal of Advanced Research, v. 11, 33 41. https://doi.org/10.1016/j.jare.2017.11.004.
Teitelbaum, J.E.; Walker, W.A., 2001. Review: The role of omega 3 fatty acids in intestinal inflammation. Journal of Nutritional Biochemistry, v. 12, (1), 21-32. https://doi.org/10.1016/S0955-2863(00)00141-8.

UTEX. The Culture Collection of Algae at the University of Texas at Austin (Accessed September 3, 2011) at: http://www.sbs.utexas.edu/utex/.

Venkatesan, R.; Vagasam, K.P.K.; Balasubramanian, T., 2006. Culture of marine microalgae in shrimp farm discharge water: a sustainable approach to reduce the cost production and recovery of nutrients. Journal of Fisheries and Aquatic Science, v. 1, (3), 262-269. https://dx.doi.org/10.3923/jfas.2006.262.269

Verlengia, R.; Lima, T.M., 2002. Síntese de Ácidos Graxos. In: Curi, R.; Pompeia, C.; Miyasaka, C.K.; Procópio, J. (Eds.). Entendendo a gordura: os ácidos graxos. Manole, São Paulo, pp. 121-134.

Wang, S.T.; Pan, Y.Y.; Liu, C.C.; Chuang, L.T.; Chen, C.N.N., 2011. Characterization of a green microalga UTEX 2219-4: Effects of photosynthesis and osmotic stress on oil body formation. Botanical Studies, v. 52, (3), 305-312.

Yeh, K.-L.; Chang, J.-S., 2012. Effects of cultivation conditions and media composition on cell growth and lipid productivity of indigenous microalga Chlorella vulgaris ESP-31. Bioresource Technology, v. 105, 120-127. https://doi. org/10.1016/j.biortech.2011.11.103.

Zhao, P.; Yu, X.; Li, J.; Tang, X.; Huang, Z., 2014. Enhancing lipid productivity by co-cultivation of Chlorella sp. U4341 and Monoraphidium sp. FXY-10. Journal of Bioscience and Bioengineering, v. 118, (1), 72-77. https://doi. org/10.1016/j.jbiosc.2013.12.014. 